\title{
Selenium Supplementation of Lactating Dairy Cows: Effect on Selenium Concentration in Blood, Milk, Urine, and Feces
}

\author{
D. T. Juniper, ${ }^{\star}$ R. H. Phipps, ${ }^{* 1}$ A. K. Jones, ${ }^{\star}$ and G. Bertin† \\ ${ }^{*}$ Centre for Dairy Research, School of Agriculture, Policy and Development, University of Reading, RG6 6AR Reading, UK \\ †Alltech France, EU Regulatory Department, 14 Place Marie-Jeanne Bassot, 92300 Levallois-Perret, France
}

\begin{abstract}
The objectives were to determine effects of graded levels of selenized yeast derived from a specific strain of Saccharomyces cerevisiae (CNCM I-3060) on animal performance and in selenium concentrations in the blood, milk, feces, and urine of dairy cows compared with sodium selenite; and to provide preliminary data on the proportion of selenium as selenomethionine in the milk and blood. Twenty Holstein cows were used in a $5 \times 5$ Latin square design study in which all cows received the same total mixed rations, which varied only in source or concentration of dietary selenium. There were 5 experimental treatments. Total dietary selenium of treatment 1 , which received no added selenium, was $0.15 \mathrm{mg} / \mathrm{kg}$ of dry matter, whereas values for treatments 2,3 , and 4 , derived from selenized yeast, were $0.27,0.33$, and $0.40 \mathrm{mg} / \mathrm{kg}$ of dry matter, respectively. Treatment 5 contained $0.25 \mathrm{mg}$ of selenium obtained from sodium selenite/kg of dry matter. There were no significant treatment effects on animal performance, and blood chemistry and hematology showed few treatment effects. Regression analysis noted significant positive linear effects of increasing dietary selenium derived from selenized yeast on selenium concentrations in the milk, blood, urine, and feces. In addition, milk selenium results indicated improved bioavailability of selenium from selenized yeast, compared with sodium selenite. Preliminary analyses showed that compared with sodium selenite, the use of selenized yeast increased the concentration of selenomethionine in the milk and blood. There was no indication of adverse effects on cow health associated with the use of selenized yeast.
\end{abstract}

Key words: dairy cow, selenized yeast, sodium selenite, selenomethionine

\section{INTRODUCTION}

Selenium is recognized as an essential trace element, and its deficiency has been associated with impaired

Received October 3, 2005.

Accepted April 28, 2006.

${ }^{1}$ Corresponding author: r.h.phipps@reading.ac.uk growth, fertility, and health in farm livestock (Schwarz and Foltz, 1957; Weiss et al., 1990). Selenium is also an essential nutrient for human health, and its role has been reviewed recently (Rayman, 2000, 2004). Rayman reported that between 1975 and 1995, selenium intake in the United Kingdom decreased from around 60 to 34 $\mu \mathrm{g} / \mathrm{d}$ per person, which means that the current intake is about half of the UK Reference Nutrient Intake. This decline has caused concern because suboptimal selenium intake is associated with a number of serious health issues, including reduced immune function, cardiomyopathy, depressed mood, and increased incidence of cancer.

Although meeting dietary selenium requirements is an important nutritional requirement for livestock, mineral supplementation may also enhance the nutritional quality of the livestock product. In the European Union only inorganic sources of selenium, sodium selenate and sodium selenite (SS), are currently approved as feed additives, with a maximal legal dose rate of $0.5 \mathrm{mg}$ of selenium $/ \mathrm{kg}$ of DM (Ministry of Agriculture, Fisheries and Food, 2000). This value is higher than the limit of $0.3 \mathrm{mg}$ of selenium $/ \mathrm{kg}$ of DM set by FDA regulations in the United States, where both inorganic and organic sources of selenium, such as selenized yeast (SY), are approved.

A number of studies reviewed by Weiss (2005) and recent work reported by Givens et al. (2004) have established that, compared with inorganic sources of selenium, the use of SY resulted in a large and significant increase in milk selenium concentration, which was suggested as one route for increasing selenium intake in humans in areas where selenium intake was below optimum.

The majority of selenium in body tissues and fluids is present as either selenocysteine (SeCys), which functions as an active center for selenoproteins, or selenomethionine (SeMet), which is incorporated into general proteins and acts as a biological pool for selenium ( $\mathrm{Su}-$ zuki and Ogra, 2002). Early work by Allen and Miller (1980) studied the distribution and binding of additional selenium ${ }^{75}$ in goat and cow milk. More recent studies have shown that selenium absorption occurs in the small intestine and that although SeMet is absorbed 
via the methionine transporter system, the absorption of SS is less efficient and occurs mainly by passive diffusion (Weiss, 2003). Further work has reported that irrespective of source, selenium must undergo a metabolic transformation prior to its assimilation into SeCys and subsequent incorporation into selenoproteins. However, no such intermediate step is necessary for the incorporation of SeMet into general proteins. Although improvements in analytical methodology can provide the opportunity to determine the contribution of specific selenium fractions in livestock products, very little information has been published in this area.

The aims of the current study were 2-fold: The first was to determine the effect of an increasing level of SY on animal performance and to determine selenium concentrations in the blood, milk, feces, and urine of high-yielding Holstein dairy cows, compared with a standard inclusion of SS; and the second was to provide preliminary data comparing the proportion of Se incorporated as SeMet in the milk and blood of animals receiving either SS or SY at comparable dietary selenium concentrations.

\section{MATERIALS AND METHODS}

\section{Cows, Experimental Design, and Diets}

The work was conducted under the authority of the UK Animals (Scientific Procedures) Act 1986 (Home Office, 1986) and under the control of staff holding appropriate licenses under the Act. All cows were housed in cubicle yards with sawdust for bedding and with ad libitum access to potable water.

Twenty multiparous Holstein cows, which had completed $54 \pm 8.5$ DIM, and with an initial BW of $647 \pm$ $76 \mathrm{~kg}$, and producing $38.1 \pm 2.8 \mathrm{~kg} / \mathrm{d}$ of milk yield were used in a $5 \times 5$ Latin square design feeding trial made up of 4 squares and 5 periods, with each period lasting 5 wk. The design was balanced for residual effects of treatments in the succeeding period. All cows received the same TMR, which contained corn silage, grass silage, cracked wheat, soybean meal, rapeseed meal, and minerals at $375,125,250,135,100$, and $15 \mathrm{~g} / \mathrm{kg}$ of total dietary DM, respectively. The cracked wheat, soybean meal, and rapeseed meal were blended to produce a concentrate supplement that was added as a single component to the TMR. The TMR varied only in the source or concentration of dietary selenium. There were 5 experimental treatments: The total dietary selenium of treatment 1 (T1), with no added selenium, was $0.15 \mathrm{mg}$ of selenium $/ \mathrm{kg}$ of DM, whereas the values for treatments 2,3 , and 4 (T2, T3, T4) were, respectively, 0.27, 0.33 , and $0.40 \mathrm{mg}$ of selenium derived from SY/kg of DM. Treatment 5 (T5) contained $0.25 \mathrm{mg}$ of selenium derived from $\mathrm{SS} / \mathrm{kg}$ of DM.
The mineral supplements used (Dairy Direct International, Ashford, Kent, UK) were based on a commercially available product and contained, on a DM basis, $270 \mathrm{~g} / \mathrm{kg}$ calcium, $40 \mathrm{~g} / \mathrm{kg}$ phosphorus, $60 \mathrm{~g} / \mathrm{kg}$ magnesium, $40 \mathrm{~g} / \mathrm{kg}$ sodium, $50 \mathrm{mg} / \mathrm{kg}$ cobalt carbonate, 500 $\mathrm{mg} / \mathrm{kg}$ calcium iodate, $4,000 \mathrm{mg} / \mathrm{kg}$ manganese oxide, $5,000 \mathrm{mg} / \mathrm{kg}$ zinc oxide, $1,500 \mathrm{mg} / \mathrm{kg}$ cupric sulfate, 15 $\mathrm{mg} / \mathrm{kg} \mathrm{SS}$, and 500,000, 100,000, and $500 \mathrm{IU} / \mathrm{kg}$ of vita$\min \mathrm{A}, \mathrm{D}_{3}$, and $\mathrm{E}$. The mineral supplement produced for use in T1 to T5 was identical to the commercial supplement described above except that the selenium was replaced with $0,0.15,0.30$, or $0.45 \mathrm{mg}$ of selenium derived from SY (Sel-Plex; Alltech, Nicholasville, KY)/ $\mathrm{kg}$ of total diet DM for use in T1, T2, T3, and T4, respectively, and $0.15 \mathrm{mg}$ of selenium derived from SS/kg of DM for use in T5.

On a given date, the 20 cows were allocated to the 5 treatments on the basis of milk yield, parity, calving date, and BW. A predesigned blocking matrix was used to determine the treatment to which animals were assigned. For animals to be accepted within a block, they had to have calved within $28 \mathrm{~d}$ of each other, have milk yields and BW within $3 \mathrm{~kg} / \mathrm{d}$ and $50 \mathrm{~kg}$ (as measured in the 2 previous wk), and be of the same parity. Each treatment period lasted $5 \mathrm{wk}$, with wk 1 to 4 being for adaptation and wk 5 being for data collection and analysis.

\section{Sampling Procedures and Measurements}

Feed Analyses. In wk 5 of each period, daily samples $(250 \mathrm{~g} / \mathrm{sample})$ of corn silage $(36.9 \% \mathrm{DM})$, grass silage (27.3\% DM), and concentrate supplement were collected and frozen $\left(-20^{\circ} \mathrm{C}\right)$. At the end of the study, the samples for each period were bulked and then subsampled to provide a single sample for each ration component for each period. Silage samples were analyzed for a full range of nutritional and fermentation characteristics (Natural Resources Management, Bracknell, UK). Oven-dried $\left(60^{\circ} \mathrm{C}\right.$ until static weight) silage samples were analyzed for DM, CP, NDF, starch, and watersoluble carbohydrates using near-infrared spectroscopy (Foss 5000 NIR systems; Foss Electric, York, UK). The $\mathrm{ME}$ concentrations for grass silage, corn silage, and concentrate supplement were estimated (Givens et al., 1995; Offer et al., 1996). Gas chromatography (Agilent 6890 Series GC system; Agilent Technologies, Inc., Palo Alto, CA) was used to determine silage fermentation characteristics. The concentrate supplement was analyzed for DM, CP, NDF, starch, water-soluble carbohydrates, oil, and ME content using wet chemistry methods (Ministry of Agriculture, Fisheries and Food, 1993).

The results of the analyses obtained for the silages and the concentrate supplements were used to calculate 
the nutritional value of the TMR offered during the experimental period.

Feed Intake. Fresh TMR were prepared daily in a Hi-Spec mixer feeder wagon (Hi-Spec, Bagenalstown, Co. Carlow, Ireland) and offered on an individual cow basis at $0900 \mathrm{~h}$ through an electronic feeding gate system (American Calan, Northwood, NH). To ensure cows had ad libitum access to the TMR, the amount to be offered to individual cows was assessed on a daily basis with the aim of producing a 5 to $10 \%$ refusal. Because of labor constraints, refusals were removed $(0700 \mathrm{~h})$ and measured 3 times a week (Monday, Wednesday, and Friday). Individual daily feed intakes were calculated on a weekly basis by subtracting the refusals measured during that week from the total fresh TMR offered in that week. The DM content of the TMR for that week was then applied to both the offered and refused feed to estimate the individual daily DMI on a weekly basis. In these calculations, the DM contents of the offered and refused TMR were assumed to be the same.

Milk Yield and Composition. Cows were milked twice daily at 0500 and $1500 \mathrm{~h}$ through a Fullwood herringbone parlor with automatic cow identification, automatic cluster removal, and Fullflow inline milk meters (Fullwood Co., Ellesmere Port, UK) to record and sample milk. Individual milk yields were recorded automatically for all cows at each milking. In wk 5 of each period, $25-\mathrm{mL}$ milk samples from 2 consecutive milkings (Tuesday p.m. and Wednesday a.m.) were analyzed for fat, protein (total nitrogen $\times 6.38$ ), and lactose concentrations using an infrared milk analyzer (Foss Electric). These data were combined with the corresponding milk yields to produce mean weekly milk composition data. The yields of milk constituents were calculated using average weekly a.m. and p.m. milk yield and milk composition data. Two extra milk samples were taken on Tuesday p.m. and subsequently analyzed for milk urea concentration using a Combifoss 6000 analyzer (Foss, Hillerød, Denmark), and SCC were determined by fluorescence flow cytometry and cell counting using a Somascope MKII2 (Delta Instruments, Norwood, MA).

Blood Chemistry and Hematology. Blood samples were taken from the tail vein of all cows in the final week of each period. Six 5-mL Vacutainers (3 lithium heparin, $1 \mathrm{~K}_{3}$ EDTA, 1 oxalate-sodium fluoride, and 1 serum tube; Becton Dickinson, Plymouth, UK) were filled per cow. The blood chemistry parameters measured included alanine transferase, glutamate dehydrogenase, albumin, globulin, urea, total protein, inorganic phosphate, creatinine phosphokinase, alkaline phosphatase, lactic dehydrogenase, aspartate aminotransferase, $\gamma$-glutamyl transferase, glucose, and glutathione peroxidase (GSH-Px), whereas the hematological parameters included erythrocyte count, hemoglobin con- tent, mean corpuscular volume, packed-cell volume, mean corpuscular hemoglobin, thrombocytes, total leukocytes, segmented neutrophils, banded neutrophils, lymphocytes, monocytes, eosinophils, and basophils. Standard analytical techniques were used for these analyses (Compton Paddock Laboratories, Yattendon, Berkshire, UK).

Selenium Analyses. Inductively coupled plasma mass spectrometry (Elan 6100; PerkinElmer, Norwood, MA) was used to analyze feed, milk, blood, urine, and fecal samples for total selenium and the concentration of SeMet in milk and blood. Feed samples prepared for routine analysis, as described above, were also used to determine the total dietary selenium concentration. In addition to milk samples taken for standard compositional analyses, extra samples were taken on Thursday a.m. during wk 5 of each period through an automatic sampling device fitted to the meters in the parlor. Samples were then poured into 50-mL screw-topped bottles, wrapped in Parafilm, and subsequently analyzed for total selenium. Selenomethionine analyses were determined only on bulked milk samples obtained for each treatment in wk 5 of each period.

Two of the blood samples taken into lithium heparin tubes from the tail vein of all animals in wk 5 of each period were analyzed for total selenium and SeMet concentrations. Total selenium was determined on one complete set of samples, whereas the SeMet concentration was determined only on blood samples that had been bulked for each treatment of each period.

Urine and feces samples were collected from all animals during the final week of periods 3,4 , and 5 for total selenium analyses. Approximately $25 \mathrm{~mL}$ of urine and $250 \mathrm{~g}$ of feces were collected, placed in plastic containers, immediately frozen, and subsequently analyzed for total selenium.

Prior to the start of the study, 2 samples of the SY to be used (Sel-Plex, batch number SEK-941; Alltech) were analyzed for total selenium concentration, and a value of $2,123 \pm 46 \mu \mathrm{g}$ of selenium/g of DM was recorded. The mineral supplements used in $\mathrm{T} 1$ to $\mathrm{T} 5$ were produced as a single consignment. In wk 5 of each period, a 200 -g sample of each mineral supplement was taken, and at the end of the study it was bulked on a treatment basis and subsampled prior to analysis for total selenium concentration. The selenium values in SY and the mineral supplements were analyzed using inductively coupled plasma mass spectrometry (PerkinElmer).

\section{Statistical Analysis}

The results of the feeding study were analyzed using a general linear modeling procedure for a Latin square design using the statistical package Genstat 7 (Lawes 
Table 1. Estimated nutritional analysis of TMR based on analyses of ration ingredients sampled on a monthly basis during the experimental period

\begin{tabular}{lcc}
\hline $\begin{array}{l}\text { Ingredient, } \\
\text { g/kg of DM }\end{array}$ & $\begin{array}{l}\text { Composition } \\
\text { of TMR }\end{array}$ & SEM \\
\hline $\mathrm{DM}$ & 494 & 19.8 \\
$\mathrm{ME}, \mathrm{MJ} / \mathrm{kg}$ of DM & 11.9 & 0.11 \\
$\mathrm{NDF}$ & 322 & 14.8 \\
$\mathrm{CP}$ & 209 & 11.7 \\
Ash & 53 & 1.9 \\
Starch & 275 & 14.6 \\
Sugar & 33 & 4.0 \\
Oil-B & 33 & 2.6 \\
\hline
\end{tabular}

${ }^{1}$ Unless otherwise stated.

${ }^{2}$ Total oil as measured by Ministry of Agriculture, Fisheries and Food (1993).

Agricultural Trust, 2003). Sources of variation within the model included cows ( $19 \mathrm{df})$, periods within squares (16 df), and treatments ( $4 \mathrm{df})$. The $5 \%$ level of significance was considered for the tests of significance. One cow did not complete period 5 (T3) because of damaged hip ligaments. Comparisons were made between treatment means as follows: 1) Treatment 2 (SY) and T4 (SS) were compared using Student's $t$-test because they had similar levels but different sources of selenium. 2) The dose response to level of SY in the TMR was considered for treatment means $\mathrm{T} 1, \mathrm{~T} 2$, T3, and T4.

\section{RESULTS AND DISCUSSION}

\section{Feed Analyses}

Based on the inclusion rates and compositional analyses of the forages, concentrates, and mineral supplements included in the TMR, the nutritional composition of the TMR fed to the dairy cows, together with their total dietary selenium concentrations, were estimated (Table 1). Analysis of a bulked sample of the SY used in the study showed that $99 \%$ of the total selenium content was in an organic form, with $63 \%$ as SeMet and $36 \%$ as other organic components.

\section{Feed Intake and Milk Production}

There were no significant treatment effects for either source or level of selenium on DMI, milk yield, milk composition (fat, protein, lactose, MUN, SCC), and yield of milk constituents (Table 2). Although milk yield responses have been recorded in studies in New Zealand, where pastures often contain very low selenium concentrations, the results of the current study support the general view that selenium source and concentration are unlikely to markedly affect either milk yield or concentrations of fat, protein, and lactose (Givens et al., 2004). Although Weiss et al. (1990) established a positive relationship between increasing plasma selenium concentrations in lactating dairy cows and bulk tank SCC in dairy herds in Ohio, there was no evidence in the current study to support this view, perhaps because the values were already low.

\section{Blood Chemistry and Hematology}

The results of the extensive analyses for blood chemistry and hematological parameters are presented in Table 3. With the exception of blood urea and glucose values, there were no significant treatment effects for either source or concentration of selenium, and even when significant differences were recorded, they were small and considered to have limited biological meaning because they were generally within the expected normal range (Beers and Berkow, 1998). The activity of the selenoenzyme GSH-Px is often considered to reflect the selenium concentration of whole blood. In the current study there were no significant treatment effects for either source or concentration of dietary selenium on GSH-Px. The lack of a significant effect for source of dietary selenium on GSH-Px activity supports the review of 11 studies cited by Weiss (2003), in which 9 reported no significant difference in GSH-Px activity when comparing SY with SS, even though the values were generally numerically higher. Ortman and Pehrson (1999) noted that in a 12 -wk study comparing the effect of selenium source, the GSH-Px activity in cows receiving either selenate, SS, or SY remained relatively constant for the first 6 wk of the study, but then increased markedly in wk 6 to 12, with the highest values noted for cows receiving the diet containing SY. In the current study it is possible that the 5 -wk periods in the Latin square design were not long enough for differences in GSH-Px activity to develop (Table 3).

\section{Selenium Concentrations in Blood, Milk, Feces, and Urine}

The selenium concentrations in blood, milk, feces, and urine for the 5 treatments and the linear effects are shown in Table 4.

Blood. The source of dietary selenium did not significantly effect selenium concentrations in whole blood, which were 214 and $208 \mu \mathrm{g} / \mathrm{L}$ for SY (T2) and SS (T5), respectively (Table 4). Although Knowles et al. (1999) and Fisher et al. (1995) both showed a similar result in dairy cows, a review by Weiss (2003) of 10 studies with a range of livestock (dairy cows, heifers, and steers) reported an average 18\% increase in whole blood selenium concentration when animals received SY rather than SS. The response was noted particularly in studies in which the total dietary selenium intake in the control group was relatively low, as in one study 
Table 2. Mean values for milk yield; milk fat, protein, and lactose; SCC; MUN concentration; and DMI for cows receiving increasing rates of selenized yeast (Saccharomyces cerevisiae CNCM I-3060) in treatments 1 to 4 (T1 to T4), and sodium selenite in treatment 5 (T5)

\begin{tabular}{|c|c|c|c|c|c|c|}
\hline \multirow[b]{2}{*}{ Item } & \multicolumn{5}{|c|}{ Treatment } & \multirow{2}{*}{$\begin{array}{l}\text { SEM, } \\
59 \mathrm{df}\end{array}$} \\
\hline & $\mathrm{T} 1$ & $\mathrm{~T} 2$ & T3 & $\mathrm{T} 4$ & T5 & \\
\hline Total dietary selenium, $\mathrm{mg} / \mathrm{kg}$ of $\mathrm{DM}$ & 0.15 & 0.27 & 0.33 & 0.40 & 0.25 & \\
\hline Milk yield, kg/d & 31.3 & 31.5 & 30.4 & 31.0 & 30.6 & 0.48 \\
\hline \multicolumn{7}{|l|}{ Composition, g/kg } \\
\hline Fat & 42.2 & 44.4 & 44.2 & 43.0 & 43.4 & 0.66 \\
\hline Protein & 35.4 & 35.0 & 35.4 & 35.4 & 34.9 & 0.20 \\
\hline Lactose & 45.7 & 45.4 & 45.5 & 45.7 & 45.8 & 0.21 \\
\hline \multicolumn{7}{|l|}{ Constituent yield, g/d } \\
\hline Fat & 1,317 & 1,392 & 1,324 & 1,325 & 1,320 & 28.5 \\
\hline Protein & 1,106 & 1,098 & 1,067 & 1,093 & 1,057 & 17.5 \\
\hline Lactose & 1,429 & 1,431 & 1,382 & 1,417 & 1,398 & 22.9 \\
\hline $\mathrm{SCC}, \log _{10}$ & 5.14 & 5.22 & 5.14 & 5.18 & 5.20 & 0.083 \\
\hline MUN, mg/L & 213 & 215 & 214 & 224 & 208 & 6.9 \\
\hline Total DMI, kg/d & 23.5 & 23.7 & 23.2 & 23.4 & 23.1 & 0.33 \\
\hline
\end{tabular}

${ }^{1}$ Standard error of the treatment mean for 20 cows.

conducted by Knowles et al. (1999), in which total dietary intake was $2 \mathrm{mg}$ of selenium/d, but not in a second study in which selenium intake was $4 \mathrm{mg} / \mathrm{d}$. Thus, the lack of response in the current trial may be associated with the fact that the total dietary selenium intakes for SY and SS of 6.34 and $5.85 \mathrm{mg} / \mathrm{d}$, respectively, were above the threshold at which a response would be recorded.

When the total dietary concentration of selenium was increased from 0.15 to $0.40 \mathrm{mg} / \mathrm{kg}$ of DM by increasing

Table 3. Mean values for blood chemistry and hematology for animals receiving increasing rates of selenized yeast in treatments 1 to 4 (T1 to T4), and sodium selenite in treatment 5 (T5)

\begin{tabular}{|c|c|c|c|c|c|c|}
\hline \multirow[b]{2}{*}{ Item } & \multicolumn{5}{|c|}{ Treatment } & \multirow{2}{*}{$\begin{array}{l}\text { SEM, } \\
59 \mathrm{df}\end{array}$} \\
\hline & $\mathrm{T} 1$ & $\mathrm{~T} 2$ & T3 & $\mathrm{T} 4$ & T5 & \\
\hline Total dietary selenium, $\mathrm{mg} / \mathrm{kg}$ of $\mathrm{DM}$ & 0.15 & 0.27 & 0.33 & 0.40 & 0.25 & \\
\hline Red blood cells, $\times 10^{12} / \mathrm{L}$ & 6.1 & 6.1 & 6.0 & 6.1 & 6.0 & 0.07 \\
\hline White blood cells, $\times 10^{9} / \mathrm{L}$ & 8.8 & 8.3 & 8.6 & 8.8 & 9.1 & 0.44 \\
\hline Hemoglobin, g/dL & 10.6 & 10.6 & 10.5 & 10.7 & 10.5 & 0.11 \\
\hline Packed-cell volume, \% & 29.7 & 29.5 & 29.5 & 29.7 & 29.4 & 0.32 \\
\hline Mean corpuscular volume, fL & 48.8 & 48.9 & 48.9 & 48.7 & 49.1 & 0.14 \\
\hline Mean corpuscular hemoglobin, g/dL & 35.6 & 35.8 & 35.6 & 36.0 & 35.7 & 0.12 \\
\hline Thrombocytes (platelets), $\times 10^{9} / \mathrm{L}$ & 402 & 401 & 355 & 369 & 386 & 18.4 \\
\hline Segmented neutrophils, \% & 13.3 & 13.3 & 19.5 & 14.6 & 10.5 & 1.99 \\
\hline Banded neutrophils, \% & 1.0 & 1.6 & 3.6 & 1.9 & 1.7 & 0.58 \\
\hline Lymphocytes, \% & 42.9 & 44.3 & 37.6 & 43.3 & 41.9 & 1.75 \\
\hline Monocytes, \% & 6.7 & 7.1 & 5.5 & 6.6 & 7.4 & 0.53 \\
\hline Eosinophils, \% & 5.6 & 5.6 & 6.0 & 5.6 & 4.7 & 0.75 \\
\hline Basophils, \% & 30.7 & 28.3 & 28 & 28.2 & 33.9 & 2.49 \\
\hline Alkaline phosphate, $\mathrm{U} / \mathrm{L}$ at $37^{\circ} \mathrm{C}$ & 93.1 & 98.3 & 99.1 & 96.0 & 93.4 & 2.12 \\
\hline Creatinine kinase, $\mathrm{U} / \mathrm{L}$ at $37^{\circ} \mathrm{C}$ & 143 & 142 & 132 & 119 & 135 & 14.6 \\
\hline$\gamma$-Glutamyl transferase, $\mathrm{U} / \mathrm{L}$ at $37^{\circ} \mathrm{C}$ & 41.4 & 39.4 & 41.5 & 40.1 & 40.2 & 1.22 \\
\hline Urea, $(\mathrm{mmol} / \mathrm{L})^{2}$ & 9.3 & $9.1^{\mathrm{a}}$ & 8.9 & 8.8 & $8.4^{\mathrm{b}}$ & 0.16 \\
\hline Glucose, $(\mathrm{mmol} / \mathrm{L})^{2}$ & 3.9 & $3.9^{\mathrm{b}}$ & 4.0 & 3.9 & $4.1^{\mathrm{a}}$ & 0.05 \\
\hline Total proteins, g/L & 85.2 & 84.6 & 85.3 & 83.3 & 83.7 & 0.88 \\
\hline Albumin, g/L & 34.6 & 34.4 & 35.0 & 34.7 & 34.1 & 0.34 \\
\hline Globulin (g/L) & 50.6 & 50.2 & 50.3 & 48.6 & 49.1 & 0.99 \\
\hline Glutamate dehydrogenase, U/L at $37^{\circ} \mathrm{C}$ & 40.7 & 49.0 & 44.3 & 47.4 & 45.6 & 4.13 \\
\hline Inorganic phosphate, $\mathrm{mmol} / \mathrm{L}$ & 2.2 & 2.01 & 1.98 & 2.01 & 2.0 & 0.052 \\
\hline Glutathione peroxidase, per $\mathrm{g}$ of $\mathrm{Hb}$ & 487 & 474 & 513 & 484 & 500 & 12.1 \\
\hline Alanine aminotransferase, $\mathrm{U} / \mathrm{L}$ at $37^{\circ} \mathrm{C}$ & 30 & 29.5 & 29.7 & 29.7 & 28.6 & 0.63 \\
\hline Aspartate aminotransferase, $\mathrm{U} / \mathrm{L}$ at $37^{\circ} \mathrm{C}$ & 120 & 135 & 132 & 134 & 129 & 5.6 \\
\hline Lactic dehydrogenase, $\mathrm{U} / \mathrm{L}$ at $37^{\circ} \mathrm{C}$ & 2,149 & 2,260 & 2,247 & 2,174 & 2,194 & 42.7 \\
\hline
\end{tabular}

${ }^{\mathrm{a}, \mathrm{b}}$ Means for T2 and T5 (selenium source) with different superscripts differ $(P<0.01)$.

${ }^{1}$ Standard error of treatment mean of 20 cows. 
Table 4. Mean selenium concentration and linear effects of level of dietary selenium in blood, milk, urine, and feces for cows receiving increasing inclusion rate of selenized yeast in treatments 1 to 4 (T1 to T4), and mean selenium concentrations in blood, milk, urine, and feces of cows receiving sodium selenite in treatment (T5)

\begin{tabular}{|c|c|c|c|c|c|c|c|}
\hline Item & \multicolumn{5}{|c|}{ Treatment } & $\operatorname{SEM}^{1}(\mathrm{df})$ & $\begin{array}{l}\text { Linear effect, }{ }^{2} \\
\text { per mg of selenium/ } \\
\mathrm{kg} \text { of DM }\end{array}$ \\
\hline Total dietary selenium, $\mathrm{mg} / \mathrm{kg}$ of DM & 0.15 & 0.27 & 0.33 & 0.40 & 0.25 & & \\
\hline Milk selenium, $(\mu \mathrm{g} / \mathrm{L})^{3}$ & 19.4 & $27.8^{\mathrm{a}}$ & 40.3 & 53.7 & $20.8^{\mathrm{b}}$ & $2.0(59)$ & $137 * * * \pm 10.9$ \\
\hline Urine selenium, mg/L & 0.02 & 0.05 & 0.08 & 0.14 & 0.06 & $0.007(27)$ & $0.48 * * * \pm 0.040$ \\
\hline Feces selenium, $\mathrm{mg} / \mathrm{kg}$ at $100 \% \mathrm{DM}$ & 0.37 & 0.51 & 0.65 & 0.78 & 0.58 & $0.034(27)$ & $1.65 * * * \pm 0.188$ \\
\hline
\end{tabular}

${ }^{1}$ Standard error of the treatment mean for 20 cows (mean of 12 for selenium in urine and feces).

${ }^{2}$ Mean values adjusted for residual effects.

${ }^{3}$ Means for T2 and T5 (selenium source) with different superscripts differ $(P<0.05)$.

*** $P<0.001$ (for $\mathrm{T} 1$ to $\mathrm{T} 4$ )

the inclusion rate of SY, the selenium concentration of whole blood increased from 211 to $251 \mu \mathrm{g} / \mathrm{L}$, with intermediate values for diets containing 0.27 and 0.33 $\mathrm{mg}$ of selenium/kg of DM (Table 4$)$. These data produced a highly significant $(P<0.001)$ linear effect $(162 \pm 33.4 /$ $\mathrm{mg}$ of selenium per $\mathrm{kg}$ of DM) for SY on the whole blood selenium concentration.

Although these responses were highly significant, the authors noted that they may have been limited by the relatively high background selenium concentration and that the 5-wk periods used in the experimental design may have limited red blood cell changes, and hence total selenium concentrations. However, residual effects are likely to be small because the squares in the experimental design were balanced for residual effects of treatment in the succeeding period.

Milk. The use of SY resulted in a significantly $(P<$ 0.05 ) higher milk selenium concentration of $27.8 \mu \mathrm{g} / \mathrm{L}$ compared with $20.8 \mu \mathrm{g} / \mathrm{L}$ for SS (Table 4). However, this relative increase of $34 \%$ in the concentration of selenium in milk was markedly lower than the overall mean in 10 studies reviewed by Weiss (2003), who cited a relative increase of $90 \%$.

When the total dietary concentration of selenium was increased from 0.15 to $0.40 \mathrm{mg} / \mathrm{kg}$ of DM by increasing the inclusion rate of SY, the milk selenium concentration increased from 18.9 to $53.7 \mu \mathrm{g} / \mathrm{L}$, with intermediate values for diets containing 0.27 and $0.33 \mathrm{mg}$ of selenium $/ \mathrm{kg}$ of DM. These data produced a highly significant $(P<0.001)$ linear effect $(137 \pm 10.9 / \mathrm{mg}$ of selenium per $\mathrm{kg}$ of DM) for SY on milk selenium concentration. Although few dose-response studies have been conducted with SY, the study conducted by Givens et al. (2004) also established a significant linear effect for SY on milk selenium concentration.

Givens et al. (2004) noted that the mean selenium content for milk in the United Kingdom was approximately $10 \mu \mathrm{g} / \mathrm{L}$, and that the increased selenium con- tent of milk resulting from the use of SY to replace SS could help to reduce the apparent shortfall in dietary selenium in people in the United Kingdom. The current study would support this conclusion because the milk selenium concentration was increased by $34 \%$ when SY replaced SS in dairy cow diets.

Feces and Urine. When comparing SY and SS, the results showed that the source of dietary selenium did not significantly affect the selenium concentration in either feces or urine (Table 4). However, when the total dietary concentration of selenium was increased from 0.15 to $0.40 \mathrm{mg} / \mathrm{kg}$ of $\mathrm{DM}$ by increasing the inclusion rate of SY, the selenium concentrations in feces and urine increased significantly from 0.37 to $0.78 \mathrm{mg} / \mathrm{kg}$ of $\mathrm{DM}$, and from 0.02 to $0.14 \mathrm{mg} / \mathrm{L}$, respectively, with intermediate values recorded for diets containing 0.27 and $0.33 \mathrm{mg}$ of selenium $/ \mathrm{kg}$ of DM. These data produced a highly significant $(P<0.001)$ linear effect for SY on selenium concentrations in feces $(165 \pm 0.188 / \mathrm{mg}$ of selenium per $\mathrm{kg}$ of $\mathrm{DM})$ and urine $(0.48 \pm 0.040 / \mathrm{mg}$ of selenium per $\mathrm{kg}$ of $\mathrm{DM})$. Although the current study provides useful baseline data, the subsequent fate of selenium in feces and urine needs to be explored further, especially because there is growing interest in the excretion of and potential pollution from trace elements arising from agricultural production systems.

Form of Selenium in Blood and Milk. Selenomethionine is the predominant form of selenium present in SY (Korrhola et al., 1986). Although the results presented in Table 5 are from bulked samples, the data indicate that when comparing SY with SS, not only were the total selenium concentrations in both blood and milk higher when cows received SY, but the SeMet concentration and its percentage of total selenium were also higher. These data would tend to indicate that SY has improved selenium availability compared with SS. As suggested by Pehrson (1993), the increased selenium concentration in milk derived from diets containing SY 
Table 5. Mean treatment values for total selenium and selenomethionine concentrations (mg selenium/L) and selenomethionine as percentage of total selenium in milk and blood for animals receiving increasing rates of selenized yeast in treatments 1 to 4 (T1 to T4), and sodium selenite in treatment (T5)

\begin{tabular}{lccccr}
\hline & \multicolumn{5}{c}{ Treatment } \\
\cline { 2 - 6 } Item & $\mathrm{T} 1$ & $\mathrm{~T} 2$ & $\mathrm{~T} 3$ & $\mathrm{~T} 4$ & $\mathrm{~T} 5$ \\
\hline Total dietary selenium, mg/kg of DM & 0.15 & 0.27 & 0.33 & 0.40 & 0.25 \\
Milk, mg selenium/L & & & & & \\
$\quad$ Total selenium & 24 & 36 & 45 & 64 & 25 \\
$\quad$ Selenomethionine & 4.6 & 7.5 & 11.2 & 15.5 & 4.9 \\
$\quad$ Selenomethionine, as \% total selenium & 19.1 & 20.8 & 24.8 & 24.4 & 19.6 \\
Blood, mg of selenium/L & 113 & 152 & 171 & 200 & 149 \\
$\quad$ Total selenium & 11.0 & 20.9 & 29.3 & 40.2 & 14.5 \\
$\quad$ Selenomethionine & 9.7 & 13.7 & 17.1 & 20.0 & 9.7 \\
Selenomethionine, as \% total selenium & & & & &
\end{tabular}

may be due to the preferential mammary gland uptake of SeMet, which is readily incorporated into milk protein. However, the increases seen in total milk selenium are not completely attributable to increases in SeMet, because only 25 to $33 \%$ of the increase in total Se could be accounted for by increases in SeMet alone. This would indicate that the incorporation of selenium into milk was not exclusive to the Met pathway. Milk contains a number of endogenous antioxidant enzymes, namely, glutathione peroxidase and thioredoxin reductases. These selenoproteins contain the SeCys residue, and therefore would not have been quantified within the scope of this study. Furthermore, the total selenium content of milk would also be influenced by a number of other inorganic and organic selenium species that were also not identified within the study. Recent advances in selenium analytical techniques now permit the speciation of a number of selenium-containing compounds with great precision (Palacios et al., 2005), and detailed in vivo digestion studies in conjunction with precise speciation are required to determine the true bioavailability and fate of dietary selenium in highyielding lactating dairy cows.

\section{CONCLUSIONS}

Source and concentration of dietary selenium did not significantly affect DMI; milk yield; milk fat, protein, and lactose concentrations; milk urea; and SCC; and analyses for blood chemistry and hematology showed few significant treatment effects. However, when compared with SS, the use of SY significantly increased the milk selenium concentration, indicating improved bioavailability of the selenium derived from SY. This increase in milk selenium concentration of $30 \%$ could help meet the recommended daily allowance for humans. Increasing the inclusion rate of SY also resulted in significant positive linear relationships with milk, blood, feces, and urine selenium concentrations. The use of SY resulted in a higher SeMet concentration in both blood and milk when compared with SS. Cow health was unaffected by treatment, and there was no indication of adverse effects associated with the use of the SY.

\section{ACKNOWLEDGMENTS}

The authors thank Alltech (France) for financial support to conduct the study; Sarah Potterton and Jon Siviter for technical help in conducting the study; and Rosemary Elliott for the statistical analyses.

\section{REFERENCES}

Allen, J. C., and W. J. Miller. 1980. Selenium binding and distribution in goat and cow milk. J. Dairy Sci. 63:526-531.

Beers, M. H., and R. Berkow. 1998. The Merck Veterinary Manual. http://www.merck.com Accessed May 15, 2005.

Fisher, D. D., S. W. Saxton, R. D. Elliott, and J. M. Betty. 1995. Effects of selenium sources on selenium status of lactating cows. Vet. Clin. Nutr. 2:68-74.

Givens, D. I., R. Allison, B. Cottrill, and J. S. Blake. 2004. Enhancing the selenium content of bovine milk through alteration of the form and concentration of selenium in the diet of the dairy cow. J. Sci. Food Agric. 84:811-817.

Givens, D. I., B. Cottyn, P. J. S. Dewey, and A. Steg. 1995. A comparison of the neutral detergent-cellulase method with other laboratory methods for predicting the digestibility in-vivo of maize silage from three European countries. Anim. Feed Sci. Technol. 54:55-64.

Home Office. 1986. Animal Scientific Procedures Act 1986. Her Majesty's Stationery Office, London, UK.

Knowles, S. O., N. D. Grace, K. Wurms, and J. Lee. 1999. Significance of amount and form of dietary selenium on blood, milk, and casein selenium concentrations in grazing cows. J. Dairy Sci. 82:429437.

Korrhola, M. A., A. Vainio, and K. Edelmann. 1986. Selenium yeast. Ann. Clin. Res. 18:65-68.

Lawes Agricultural Trust. 2003. Genstat 7 Package. Rothamsted Experimental Station, Rothamsted, UK.

Ministry of Agriculture,, Fisheries and Food. 2000. The Feedingstuffs Regulations. Pub. Her Majesty's Stationery Office, London, UK.

Ministry of Agriculture, Fisheries and Food. 1993. Prediction of Energy Values of Compound Feedstuffs for Farm Animals. Booklet 1285. Pub. Her Majesty's Stationery Office, London, UK.

Offer, N. W., B. R. Cotterill, and C. Thomas. 1996. Relationship between silage evaluation and animal response. Pages 26-38 in 
Proc. 11th Inter. Silage Conf. Inst. Grassld. Environ. Res., Aberystwyth, UK. Institute for Grassland and Environmental Research, Aberystwyth, UK.

Ortman, K., and B. Pehrson. 1999. Effect of selenate as a feed supplement to dairy cows in comparison to selenite and selenium yeast. J. Anim. Sci. 77:3365-3370.

Palacios, O., J. R. Encinar, G. Bertin, and R. Lobinski. 2005. Analysis of the selenium species distribution in cow blood by size exclusion liquid chromatography-inductively coupled plasma collision cell mass spectrometry (SEC-ICPccMS). Anal. Bioanal. Chem. 383:516-522.

Pehrson, B. 1993. Selenium in nutrition with special reference to biopotency of organic and inorganic selenium compounds. Pages 71-89 in Proc. 9th Alltech Symp., Biotechnol. Feed Ind. T. P. Lyons, ed. Nottingham University Press, Nottingham, UK.

Rayman, M. P. 2000. The importance of selenium to human health. Lancet 356:233-241.
Rayman, M. P. 2004. The use of high-selenium yeast to raise selenium status: How does it measure up? Br. J. Nutr. 92:557-573.

Schwarz, K., and C. M. Foltz. 1957. Selenium as an integral part of factor 3 against dietary necrotic liver degeneration. J. Am. Chem. Soc. 79:3292-3293.

Suzuki, K. T., and Y. Ogra. 2002. Metabolic pathway for selenium in the body: Speciation by HPLC-ICP MS with enriched Se. Food Addit. Contam. 19:974-983.

Weiss, W. P. 2003. Selenium nutrition of dairy cows: Comparing responses to organic and inorganic selenium forms. Pages 333343 in Proc. 19th Alltech Annual Symp. Nutr., Biotechnol. Feed Food Ind. P. T. Lyons and K. A. Jacques, ed. Nottingham University Press, Nottingham, UK.

Weiss, W. P. 2005. Selenium sources for dairy cattle. Pages 61-72 in Proc. Tri-State Dairy Nutr. Conf., Ft. Wayne, IN. The Ohio State Univ., Columbus.

Weiss, W. P., D. A. Todhunter, J. S. Hagan, and K. L. Smith. 1990. Effect of duration of supplementation of selenium and vitamin $\mathrm{E}$ on periparturient dairy cows. J. Dairy Sci. 73:3187-3194. 